\title{
PERBAIKAN, DAMPAK KOROSI PADA PESAWAT UDARA BOEING 737
}

\author{
Ali Rosyidin \\ Program Studi Teknik Mesin \\ Fakultas Teknik \\ Universitas Muhammadiyah Tangerang \\ J1. Perintis Kemedekaan 1/33, Cikokol, Kota Tangerang \\ E-mail : ali_rosyidin@yahoo.co.id
}

\begin{abstract}
ABSTRAK
Semakin meluasnya penggunaan moda transportasi udara (pesawat udara) oleh masyarakat dan menjadi pilihan, karena mempunyai kelebihan sekaligus sarana prestisius bagi masyarakat yang baru menggunakanya. Maka dari itu untuk memberikan jaminan keamanan dan keselamatan kepada masyarakat dibuatlah agenda perawatan berkala dan berkesinambungan. Baik dilakukan oleh pabrik, dinas kelaikan udara (Authority), operator maupun perusahaan perawatan pesawat udara. Karena sesungguhnya moda transportasi udara termasuk beresiko tinggi (High Risk).

Berkaca pada pengalaman berpuluh-puluh tahun dan menemui berbagai kejadian kecelakaan, maka para insinyur (Engineer) dan para awak penerbangan (Airliner) dituntut untuk terus mengembangkan kemampuannya.Termasuk selalu merevisi manualmanual penerbangan.Salah satu yang menjadi fokus perhatian dunia penerbangan adalah terjadinya korosi pada struktur pesawat terbang.

Korosi tidak dapat dihilangkan namun korosi bisa dikurangi, apalagi alam di Indonesia ini dimana kelembaban udaranya yang tinggi serta dikelilingi oleh lautan yg banyak mengandung garam.Laporan Kerja Praktek ini akan memberikan penjelasan mengenai korosi, dampak yang ditimbulkan serta penanganannya.
\end{abstract}

Kata Kunci : Transportasi Udara, Maintenance, Manual, Reparasi, Korosi, 


\section{Latar Belakang}

Pesawat udara adalah salah satu alat transportasi massal yang saat ini banyak dimanfaatkan oleh masyarakat dan menjadi pilihan karena kecepatan waktunya. Apalagi semakin berkembangnya operator-operator domestik yang memberikan harga murah dan terjangkau oleh masyarakat luas. Oleh karena moda angkutan darat kurang diminati. Namun yang menjadi tantangan didunia penerbangan saat ini, adalah keamanan dan keselamatan penerbangan menjadi taruhan akibat rendahnya harga tiket pesawat ini. Terkadang kenyamanan penumpang diabaikan dan bahkan bisa membahayakan penerbangan. Sudah banyak kejadian kecelakaan pesawat terjadi di Indonesia misal: Kejadian hilangnya pesawat Adam Air, jatuhnya pesawat Garuda di sungai bengawan solo, lepas kendalinya pesawat Lion Air sehingga menabrak kuburan di solo dan masih banyak kejadian lainya. Hal ini menumbuhkan kesadaranpara ahli kedirgantaraan akan pentingnya perawatan pesawat berkala, agar pesawat laik terbang serta membawa penumpang selamat sampai tujuan. Keamanan dan keselamatan pesawat beserta penumpangnya adalah hal yang tidak bisa ditawartawar. Demikian pentingnya hal ini maka para dirgantarawan terus selalu memperbarui kemampuan dan ilmunya agar selalu bisa mengikuti perkembangan teknologi penerbangan saat ini.

\subsection{Rumusan Masalah}

Apa itu korosi? Bagaimana proses terjadinya korosi? Bagaimana penanggulangan korosi? Jika sudah terjadi apa saja yang bisa dilakukan? begitu krusialnya korosi ini hingga pabrik, otoritas penerbangan, operator serta perusahaan perawatan pesawat udara menempatkan korosi sebagai salah satu fokus yang yang harus diperhatikan didalam perawatan pesawat udara. Sehingga diadakanlah suatu program yang khusus dalam menangani korosi ini yaitu Corrosion Preventive Control Program ( CPCP ) dan tertuang didalam Structure Repair Manual ( SRM ).

\subsection{Batasan Masalah}

Agar penulisan ini mudah difahami dan fokus sesuai dengan pembahasan maka penulisan memibatasi pada proses korosi dan penanganan dampak atau akibat yang ditimbulkan oleh korosi pada pesawat udara Boeing 737.

\subsection{Tujuan penelitian}

a. Mengetahui terjadinya korosi pada pesawat udara.

b. Mempelajari proses pemeriksaan dan perawatan pesawat udara Boeing 737

c. Mempelajari jenis - jenis penanganan dampak korosi pada Pesawat udara.

d. Cara perbaikan terhadap korosi yang timbul pada pesawat udara. 
2. PESAWAT UDARA

Pesawat mempunyai bagian bagian utama yang dibagi menjadi 5 bagian utama yaitu:

1. Fuselage / Body/ Badan

2. Engine/ Power Plant/ Mesin

3. Wing / Sayap

4. Landing Gear/ Roda Pendarat

5. Empenage / Tail Section/ Ekor

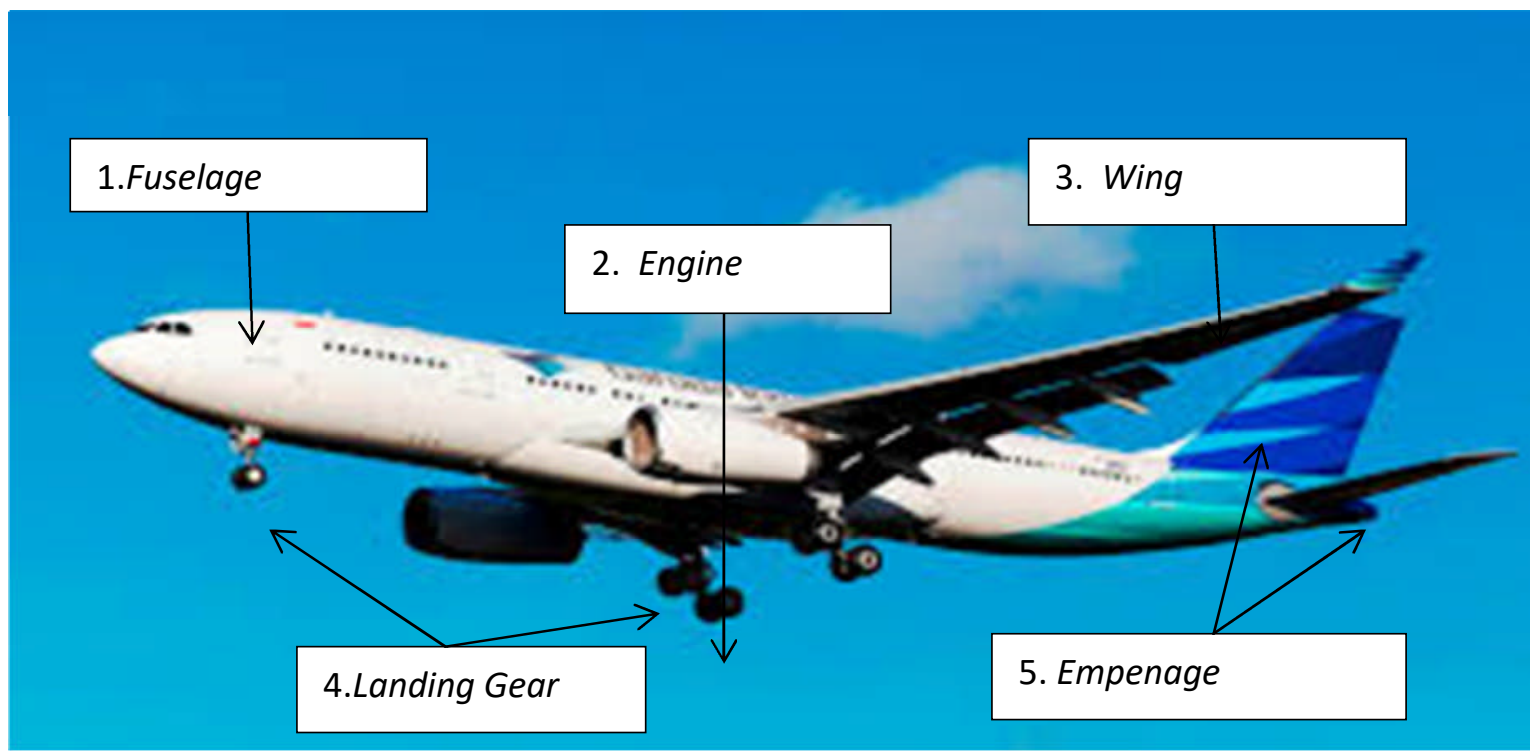

Gambar 2.1. Bagian Utama Pesawat Udara 
1. Fuselage, merupakan struktur utama dari pesawat udara, dimana terdapat ruang pilot, copilot,first officer, penumpang, cargo yang terletak pada bagian ini. Fuselage juga merupakan penghubung, pengikat antara bagian-bagian utama lainya pada pesawat udara.

2. Engine/ Power Plant/ Mesin,merupakan bagian utama pesawat udara yang menghasilkan tenaga yang digunakan sebagai tenaga pendorong pesawat udara. Bagian ini juga menghasilkan energi untuk listrik, angin ( pneumatic) dan kebutuhan pesawat lainya.

3. Wing ( sayap ) adalah bagian utama pesawat udara yang menghasilkan gaya angkat atau lift, bentuk dari wing dibuat sedemikian aerodynamic yang dimaksudkan untuk memberikan tekanan yang besar diarea bawah sayap dibandingkan dengan diatas sayap dan kecepatan diatas sayap lebih besar dibandingkan dengan dikecepatan dibawah sayap. Sayap juga dijadikan sebagai tangki bahan bakar.

4. Landing Gear / Roda Pendarat adalah bagian dari pesawat udara yang berguna untuk menyangga dan menahan beban pesawat udara ketika didarat, take off, landing, taxiing, atau stanby.

5. Empenage terletak pada bagian belakang pesawat udara (tail section). Pada empennage terdapat stabilizer dan ruang APU ( Auxiliary Power Unit ). Empenage berfungsi sebagai penyeimbang pesawatat udara sewaktu terbang atau sebagai stabilizer yang terdiri dari vertical stabilizer dan horizontal stabilizer. Horizontal stabilizer sebagai penyeimbang atau kontrol dalam menaikkan dan menurunkan pesawat atau gerakan mengangguk ( pitching ) yang bergerak pada sumbu lateral ( lateral axis ) dengan kontrol kemudi menggunakan elevator. Vertical Stabilizer sebagai penyeimbang atau kontrol dalam membelokkan pesawat yang bergerak dalam sumbu vertikal ( vertical axis ) dengan kontrol kemudi rudder dan pergerakanya dinamakan yawing.

\subsection{Proses Perawatan Pesawat Udara}

Setiap pesawat udara selama beroperasi pasti mempunyai jadwal untuk perawatan. Perawatan ini harus dilakukan karena setiap komponen mempunyai umur pemakaian tertentu sehingga komponen tersebut harus diganti. Selain itu, komponen harus diperbaiki apabila ditemukan terjadi kerusakan. Secara garis besar, program perawatan dapat dibagi menjadi dua kelompok besar. Yaitu perawatan pencegahan (preventive maintenance) dan perawatan koreksi (corective maintanance). Preventive maintenance adalah perawatan yang bertujuan mencegah terjadinya kegagalan part atau komponen sebelum komponen itu rusak. Sedangkan corective maintenance adalah perawatan yang dilakukan bertujuan memperbaiki komponen yang rusak menjadi baik kembali seperi kondisi awalnya. 
Preventive maintenance dibagi menjadi 2 jenis yaitu:

1. Perawatan Periodik atau Hard Time, merupakan perawatan yang dilakukan berdasarkan batas waktu dari umur maksimum suatu komponen pesawat. Dengan kata lain, perawatan ini merupakan perawatan pencegahan dengan cara mengganti komponen pesawat meskipun komponen tersebut belum mengalami kerusakan.

2. Perawatan On-Condition, merupakan perawatan yang memerlukan inspeksi untuk menentukan kondisi suatu komponen pesawat. Setelah itu ditentukan tindakan selanjutnya berdasarkan hasil inspeksi tersebut. Bila ada gejala kerusakan, komponen tersebut dapat diganti bila alasan-alasan teknik dan ekonominya memenuhi . Preventive maintenancedikenal juga sebagai condition monitoring yaitu perawatan yang dilakukan setelah ditemukan kerusakan pada suatu komponen, dengan cara memperbaiki komponen tersebut. Bila dengan cara perbaikan tidak dapat dilakukan maka harus dilakukan penggantian.

\subsubsection{Interval Perawatan Pesawat}

Perawatan pesawat biasanya dikelompokkan berdasarkan interval yang sepadan dalam paket-paket kerja atau disebut sebagai clustering. Hal ini dilakukan agar tugas perawtan lebih mudah, efektif, efisien. Dari jumlah tugas perawatan atau inspeksi yang dilaksanakan perawatan dibagi menjadi 2 kategori yaitu :minormaintenance dan heavy maintenance.

\section{Minor Maintenance yang erdiri dari ;}

\section{a. Transit check}

Inspeksi ini dilaksakan setiap kali setelah melakukan penerbangan saat transit di stasiun manapun. Operator biasanya memeriksa pesawat untuk memastikan bahwa pesawat tidak terdapat satupun kerusakan stuktur, semua sistem berfungsi dengan sebagaimana mestinya, dan servis yang diharuskan telah dilakukan.

\section{b. Before Departure Check}

Inspeksi ini dilakukan sedekat mungkin sebelum tiap kali pesawat berangkat beroperasi, maksimal dua jam sebelum keberangkatan.

\section{c. Daily Check}

Perawatan ini harus dilakukan satu kali dalam jangka waktu 24 jam setelah daily check sebelumnya dilakukan. Setiap hari pesawat telah diprediksi akan ground stop minimal selama empat jam. Inspeksi ini mencakup pmeriksaan komponen , pemeriksaan keliling pesawat secara langsung atau visual untuk mendeteksi ada atau tidaknya ketidaksesuaian, melakukan pengamanan lebih lanjut, dan pemeriksaan sistem operasional. 


\section{d. Weekly Check}

Pemeriksaan ini harus dilakukan dalam tujuh hari penanggalan, Termasuk dalam dalam inspeksi ini adalah before depature check.

\section{e. Preflight Check}

Pemeriksaan sekeliling pesawat sebelum pesawat siap dan di release untuk terbang. Semua persyaratan operasioanal sistem dan keamanan diperiksa secara rinci dan melalui check list formal dan dokumentasi.

\section{f. Overnight Check}

Pemeriksaan dilakukan malam hari di dalam hangar, diutamakan pada landing gearatau roda pendarat dan sistem pengereman serta ada tidaknya ditemukan benda asing atauForeign Object Damage (FOD).

\section{Heavy Maintenance}

Aircraft Maintenance Checks adalah perawatan berkala yangharus dilaksana padapesawat setelah penggunaan pesawat untuk jangka waktu tertentu, digunakan sebagai parameter interval untukHeavy Maintenance yang meliputiA-Check, $C$ Check, D-Check.

\section{A-Check :}

Dilakukan kira-kira setiap satu bulan.Pemeriksaan ini biasanya dilakukan hingga 10 jam. Pemeriksaan ini bervariasi, tergantung pada tipe pesawat, jumlah siklus ( take off) dan landing dianggap sebagai siklus pesawat, atau jam terbang sejak pemeriksaan terakhir. Perawatan pesawat jenis ini hanya melakukan pemeriksaan pada pesawat terbang untuk memastikan kelaikan mesin, system-sistem, komponenkomponen, dan struktur pesawat untuk beroperasi. Untuk Pesawat tipe Boeing 737classic, A-check dilakukan setelah 300 jam terbang, Airbus A340 setelah 450 jam terbang,Boeing 747-200 setelah 650 jam terbang

\section{C-Check:}

Dilakukan setelah 15-18 bulan . Tergantung pada tipe pesawat .Pemeriksaan ini bisa memakan waktu 10 hari, Perawatan pesawat tipe ini merupakan inspeksi komprehensiftermasuk bagian-bagian yang tersembunyi, sehingga kerusakan dan keretakandibagian dalam dapat ditemukan. Untuk Boeing 737-300 dan 737-500, inspeksi ini dilakukan setiap 4.000 FH ( flight cycle).Untuk Boeing 737-400 dilakukan setiap 4.500 FH,Sedangkan untuk Boeing 747-400 dilakukan setiap 6.400 FH dan AirBus A330- 341 dilakukan setiap 21 bulan.

\section{D-Check :}

Inspeksi ini biasa disebut overhaul. Pemeriksaan jenis ini adalah perawatan paling detail, untuk pesawat Boeing 737-300, 737-400, dan 737-500 inspeksi dilakukan setiap 24.000 FH. Sedangkan untuk Boeing 747-400 dilakukan setiap 28.00 FH dan Airbus A- 330-341 dilakukan setiap 6 tahun.Pelaksanaan perawatan jenis pesawat ini bisa memakan waktu 1 bulan. 


\subsection{Korosi}

Korosi adalah suatu fenomena alam, dimana terjadi kerusakan logam yangdisebabkan oleh reaksi kimia ataupun elektrokimia sehingga mengubah logam tersebut menjadi campuran logam seperti oxide, hydroxide.Korosi tersebut terjadi karena interaksi logam dengan keadaan sekitarnya.Korosi pada logam secara umum timbul sebagai reaksi yang diakibatkan oleh adanya elektrolit- elektrolit yang bersentuhan dengan permukaan logam.

Pesawat masa kini terbuat dari metal ringan yang memiliki daya reaktif tinggi terhadap kontaminasi di atmosfir. Garam yang terbentuk dari udara yang berasal dari daerah coastal (pantai) dan kontaminasi industri dari area urban berpengaruh terhadap struktur aluminium alloy dan magnesium, semua itu tergantung dari keputusan yang ditetapkan oleh Air Transport Association, dan biaya yang dikeluarkan sekitar 6 miliar dolar setahun untuk mengatasi masalah korosi.

Korosi merupakan reaksi elektrokimia yang menyebabkan logam untuk berubah menjadi garam dan oksida.Serbuk ini terpisah dari logam dan menyebabkan struktur logam melemah dan kehilangan kekuatannya.

Korosi logam adalah pengerusakan logam secara kimia atau elektrokimia dan mempengaruhi baik permukaan ataupun internalnya. Air atau uap air mengandung kombinasi garam dengan oksigen pada atmosfir untuk menghasilkan sumber korosi pada pesawat.

\begin{tabular}{|c|c|c|c|c|}
\hline \multirow{2}{*}{\multicolumn{2}{|c|}{ Zona Korosi }} & \multicolumn{2}{|c|}{ Laju Korosi (mm/tahun) } & \multirow{3}{*}{$\begin{array}{c}\text { Jenis Proteksi } \\
\text { Galvanise, Cat Resin }\end{array}$} \\
\hline & & \multirow{2}{*}{$\begin{array}{c}\text { Tanpa Proteksi } \\
0,30\end{array}$} & \multirow{2}{*}{$\frac{\text { Dengan Proteksi }}{0,075}$} & \\
\hline Sisi Laut & Di atas LWS & & & \\
\hline & Seabed s.d LWS & 0,15 & 0,050 & Cat Resin, Selimut Beton \\
\hline & Di bawah Seabed & 0,01 & - & - \\
\hline \multirow[t]{3}{*}{ Sisi Desa } & Atmosfir Laut & 0,10 & 0,01 & Galvanise, Cat Resin \\
\hline & Di atas air tanah residual & 0,03 & 0,01 & Primer, Cat Resin \\
\hline & Di bawah air tanah residual & 0,01 & - & - \\
\hline
\end{tabular}

Tabel 2.1. Zona Korosi

Chamberlain ( 1991 ) ; Menyatakan bahwa korosi menyebabkan kerusakan material yang disebabkan pengaruh lingkungan sekelilingnya. yang dimaksud lingkungan sekelilingnya dapat berupa lingkungan asam, udara, embun, air laut, air tawar, air danau, air sungai, dan air tanah.

\subsubsection{Mekanisme terjadinya Korosi}

Mekanisme terjadinya korosi dibagi menjadi 4 tahap yaitu :

1.Larutan logam pada anoda ( proses anoda / Anode )

2.Atom-atom logam larut kedalam lingkungan menjadi ion-ion dengan melepaskan / meninggalkan elektron- electron pada bahan 


$$
\mathrm{M}^{\mathrm{n}+}+\mathrm{ne}^{-} \longrightarrow \mathrm{M}
$$

1. Perpindaha elektron-elektron dari logam kesuatu penerima pada katoda ( proses katoda / Cathode)

$$
\mathrm{M}^{\mathrm{n}+}+\mathrm{ne}^{-} \quad \longrightarrow \mathrm{M}
$$

2. Adanya arus ion dalam larutan (Conductive medium )

3. Adanya arus electron didalam logam (Electric couple)

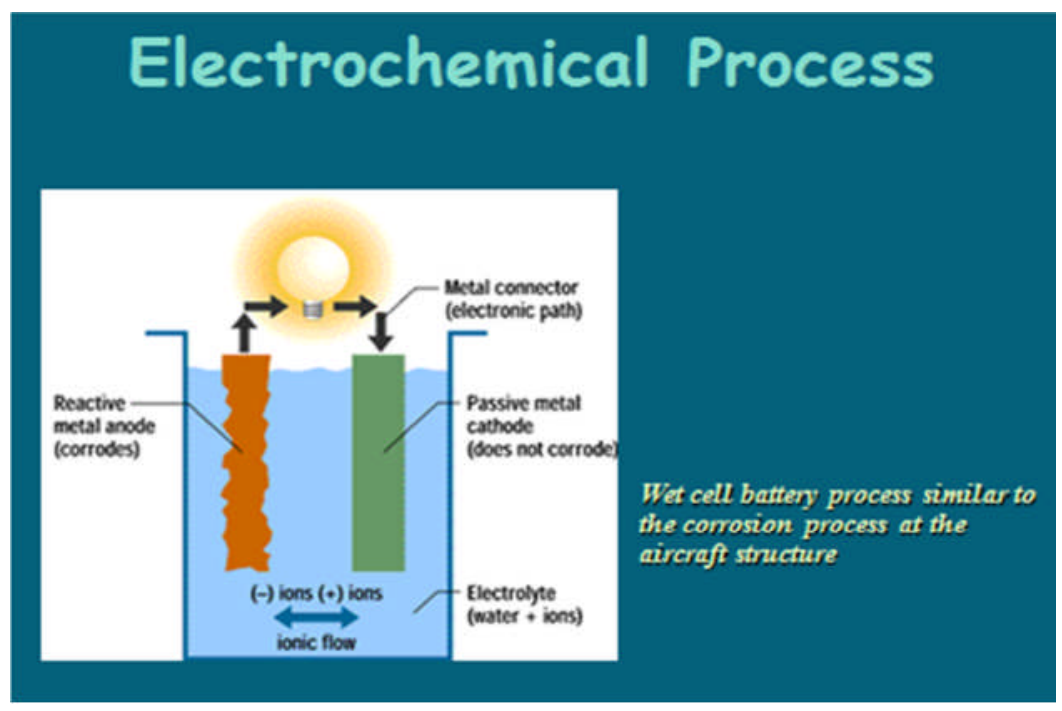

Gambar 2.2. Electrochemical Process

\subsubsection{Kondisi yang dapat Membentuk Daerah Anoda dan Katoda}

Bebrapa kondisi yang dapat membentuk daerah anoda dan katoda adalah:

1. Logam-logam yang berbeda berhubungan

2. Fasa-fasa yang beerbeda

3. Perbedaaan ukuran butiran

4. Perbedaan tegangan dan suhu

5. Perbedaan konsentrasi oksigen terlarut

\subsubsection{Faktor- factor dimana korosi berlangsung}

Faktor - factor dimana korosi dapat berlangsung antara lain:

1. Adanya daerah-daerah anoda dan katoda

2. Adanya media yang bersiafta korosif atau berfungsi elektrolit

3. Kedua daerah tersebut berhubungan secara listrik (dapat menghantarkan Electron) 


\section{3.. PENANGULANGAN KOROSI}

Untuk menentukan cara-cara penanggulangan korosi yang tepat perlu diketahui ciri-ciri serangan korosi yang terjadi dan factor penyebabnya.

Berikut ini adalah bentuk-bentuk korosi yang sering ditemukan pada pesawat terbang antara lain:

1. Kelas A : Surface Galvanic Corrosion

2. Kelas B : Dissimilar Metal Corrosion

3. Kelas C : Inter-Granular Corrosion

4. Kelas D : Stress Induced Corrosion

5. Kelas E : Microbial Corrosion

\subsection{Surface Corrosion}

Merupakan lapisan korosi yang pernah terbentuk sebelumnya, tidak menyebabkan pits atau kerusakan disekitar. Saat dimana permukaan logamyang tidak terlindungi berada pada daerah yang mengandung asap dari batere,gaslexhaust, atau kontaminasi industri maka logam akan secara keseluruhan terganggu, sehingga akan menyebabkan permukaan menjadi kusam yangdisebabkan logam yang berubah menjadi garam korosi, jika endapan ini tidakdihilangkan maka akan terbentuk logam kasar yang membentuk korosi jenis pit (corrosion pits).

Ciri-ciri :

1. Kerusakan seragam pada material.

2. Penampakan buram.

3. Pada besi hasil korosi berwarna kemerah-merahan.

4. Jika dibersihkan, permukaan logam mengkilap lagi.

Penyebab :

Akibat serangan kimia langsung (direct chemical attack).Pada kondisi udara lembab dan atmosfir mengandung unsur-unsuragresif ( missal ion CL negatif ) dibiarkan berlanjut terus, besarkemungkinan permukaan akan menjadi kasar dan berbentuklubang-lubang kecil (pitting). 


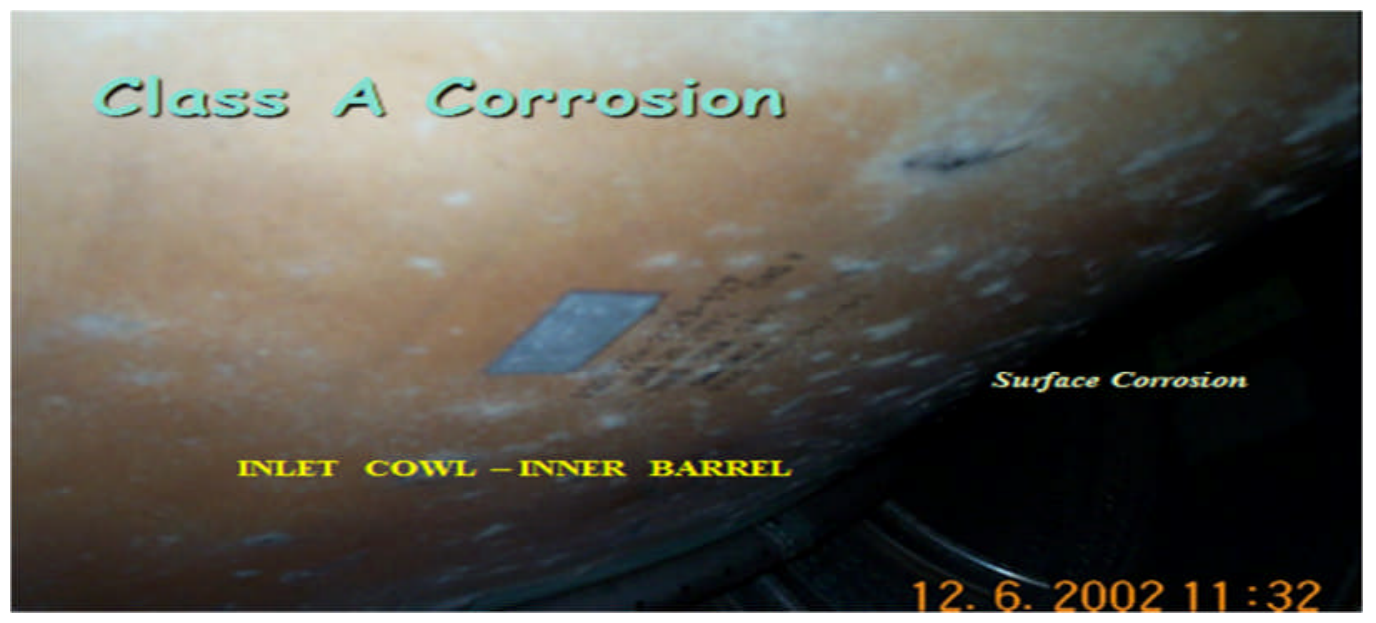

Gambar 3.1. Surface Corrosion

\subsection{Pitting Corrosion}

Merupakan pembentukan kantung dari korosi yang terjadi pada permukaan logam dan ini merupakan korosi yang terjadi akibat dari korosi yang terjadi sebelumnya tidak dihilangkan pitting terbentuk pada daerah anode. Aksi dari korosi akan terus berlangsung hingga ketebalan dari logam sudah berubah menjadi garam, secara ekstrimnya memakan seluruh bagian logam.

Ciri-cirinya :

Membentuk sumuran (pit)

Penyebab :

1. Akibat ketidak homogenan ataupun ketidak rataan permukaan

2. Aksi galvanic yang disebabkan oleh beda potensial pada daerah- daerah permukaan logam

3. Adanya ion pada elektrolit ( corrosive agent) yang menyerangdaerah-daerah yang dicurigai terjadinya "PIT" antara lain : daerah dimana logam kontak dengan material hydroskopis seperti karet,kayu, asbestos, sponge serta beberapa jenisplastik lainya juga daerah-daerah dimana sumber korosif non- naturalsepertiengineexhaust, lavatories, batteries, dll. 


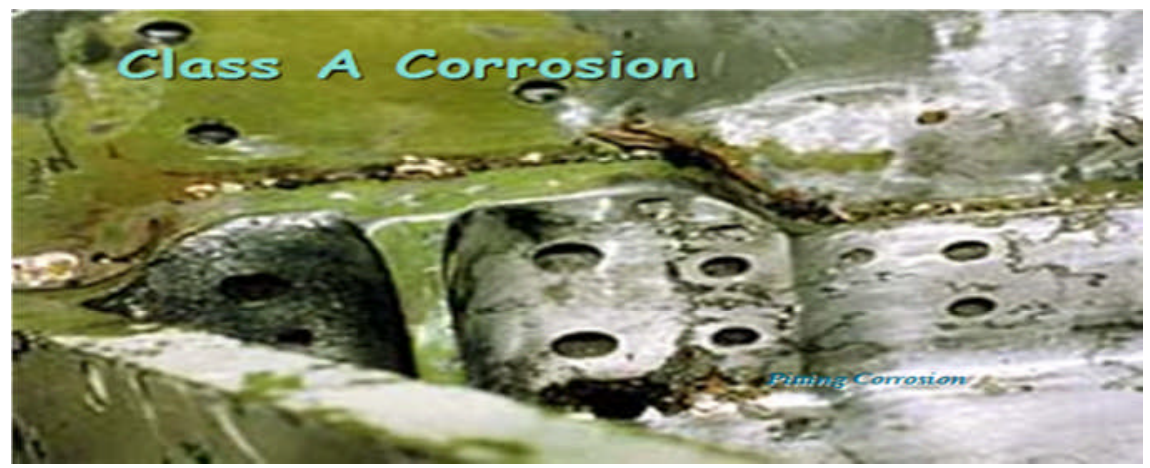

Gambar 3.2.. Pitting Corrosion

\section{3. Filliform Corrosion}

Bentuk khususnya sel oksigen yg terkonsentrasi yang terjadi pada lapisan permukaan metal ( painting/cat).

Ciri-ciri dari tipe ini:

1. Terjadinya diantara lapisan cat primer dan lapisan oksida Aluminium.

2. Cat menggelembung.

3. Terjadinya pengelupasan kearah horizontal

4. Membentuk serabut-serabut yang menyebar.

Penyebab :

1. Cat terkelupas

2.Adanya uap air yang terjebak pada lapisan primer

Penanggulangan :

1. Penambahan inhibitor yang tepat

2. Hindari pengecatan pada kekentalan udara yang tinggi 


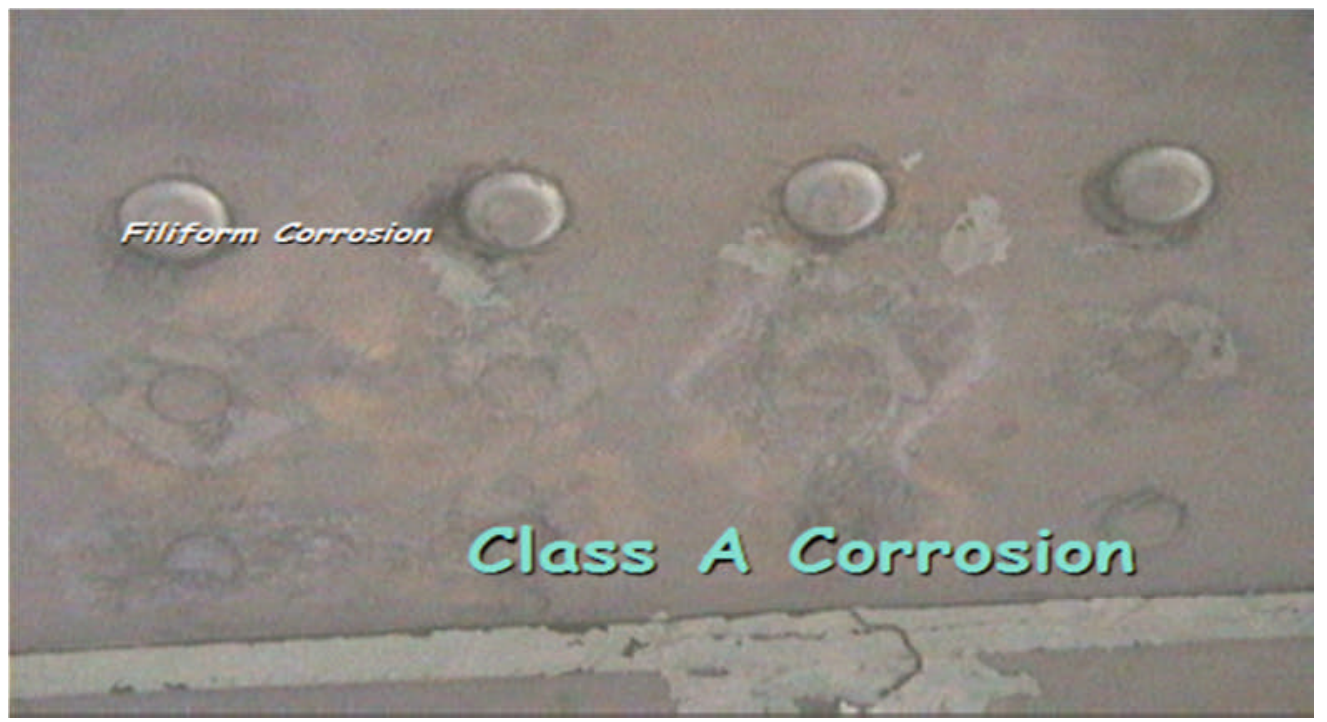

Gambar 3.3. Filliform Corrosion

\subsection{Fretting Corrosion}

Adalah jenis kerusakan yang disebabkan oleh corrosive attack,yang terjadi saat dua permukaan bertemu, subyek akan bergerak relatif.Korosi ini mempuyai pitting pada permukaannya, dan juga memiliki puing logam.

Penggunaan lubrikasi yang tepat akan meminimalkan kerusakan.

Ciri-cirinya :

1. Kerusakan pada protective film.

2. Hilangnya permukaan logam akibat oksidasi.

3. Berwarna kegelap-gelapan.

Penanggulangan :

1. Penggantian pelumas secara periodik

2. Penggunaan inhibitor/ pelindung

3. Memperkeras permukaan kedua logam jika memungkinkan

4. Pemilihan bahan / material

5. Detail design 


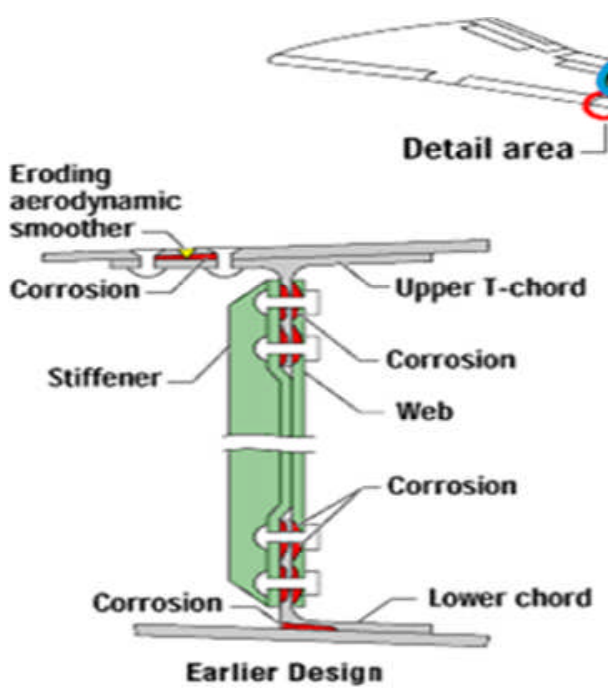

ass D Corrosion

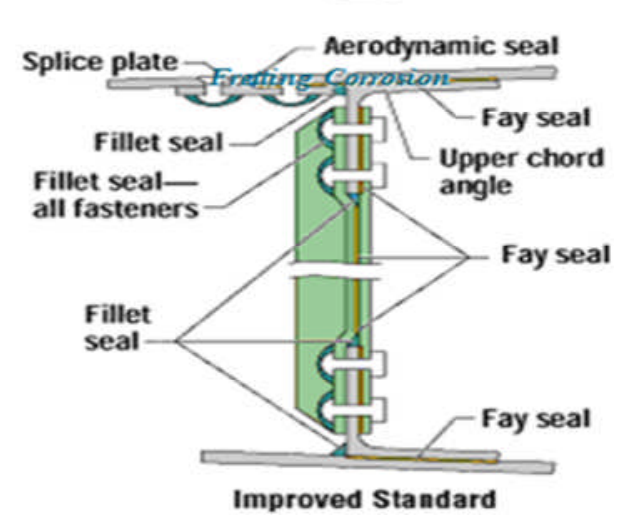

Gambar 3.4. Fretting Corrosion

\subsection{Intergranullar Corrosion}

Tampilan photo-micro dari alluminumalloy menampilkan bahwa logam ini tersusun dari susunan yang kecil yang menjadi satu ikatan; yaitu interaksi antara atom dari berbagai elemen. Pada proses heat treating, logam dipanaskan pada temperatur yang dapat membuat campuran logam tersebut menjadi solution (keadaan dimana logam dasar dan campurannya menjadi satu, sebuah logam padat) dengan yang lain. Saat temperatur ini mencapai nilai yang diinginkan, logam di keluarkan dari tungku dan sesegera didinginkan (quenching) dalam air untuk mengeraskan elemennya menjadi grain yang lebih kecil. Jika pendinginan terlambat,meskipun hanya beberapa detik, grain tersebut akan tumbuh, dan setelahpendinginan selesai, akan terbentuk daerah dissimilar metal yang akanmenyediakan katoda dan anoda yang effisien untuk pembentukan korosi.Intergranular dapat juga disebut sebagai korosi yang terjadi pada batasbutir, yang merupakan tempat berkumpulnya kemurnian atau suatu presipital, juga merupakan daerah yang lebih tegang karenanya tidak tertutup kemungkinan untuk terjadinya korosi pada batas butir (grainboundaries).

Ciri-ciri :

1. Cenderung terbentuk sepanjang garis butir

2. Paduan Alluminium yang mengandung unsur Zn ( A17075 ) peka terhadap korosi tipe ini.

\subsection{Exfoliation Corrosion}

Ini terjadi pada extruded material yang memiliki jalur atau sudut laminar (lurus) jika dibandingkan dengan logam yang diproses dengan roll atau casting, ini akan menyebabkan material menjadi delaminate (kondisi yang diakibatkan oleh exfoliation corrosion yang lapisan grain strukturnya terpisah dari yang lain Ini terjadi pada extruded material yang memiliki jalur atau sudut yang laminar (lurus) jika 
dibandingkan dengan logam yang diproses dengan roll atau casting, ini akan menyebabkan material menjadi delaminate (kondisi yang diakibatkan oleh exfoliation corrosion yang lapisan grain strukturnya terpisah dari yang lain.

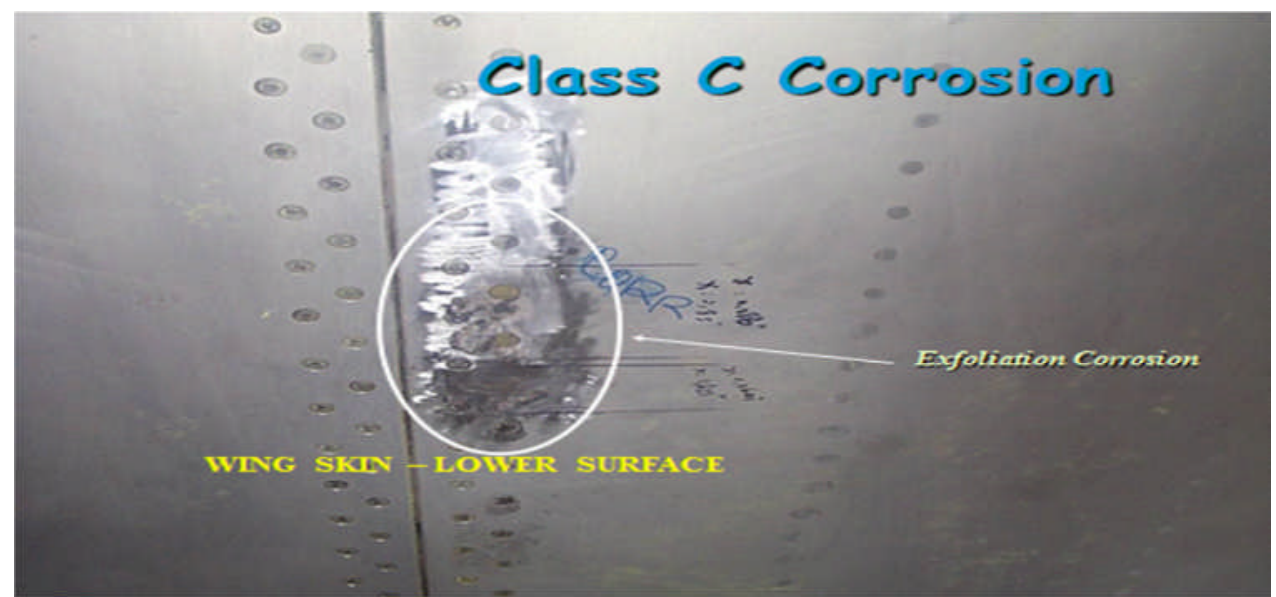

Gambar 3.5 .Exfoliation Corrosion 1

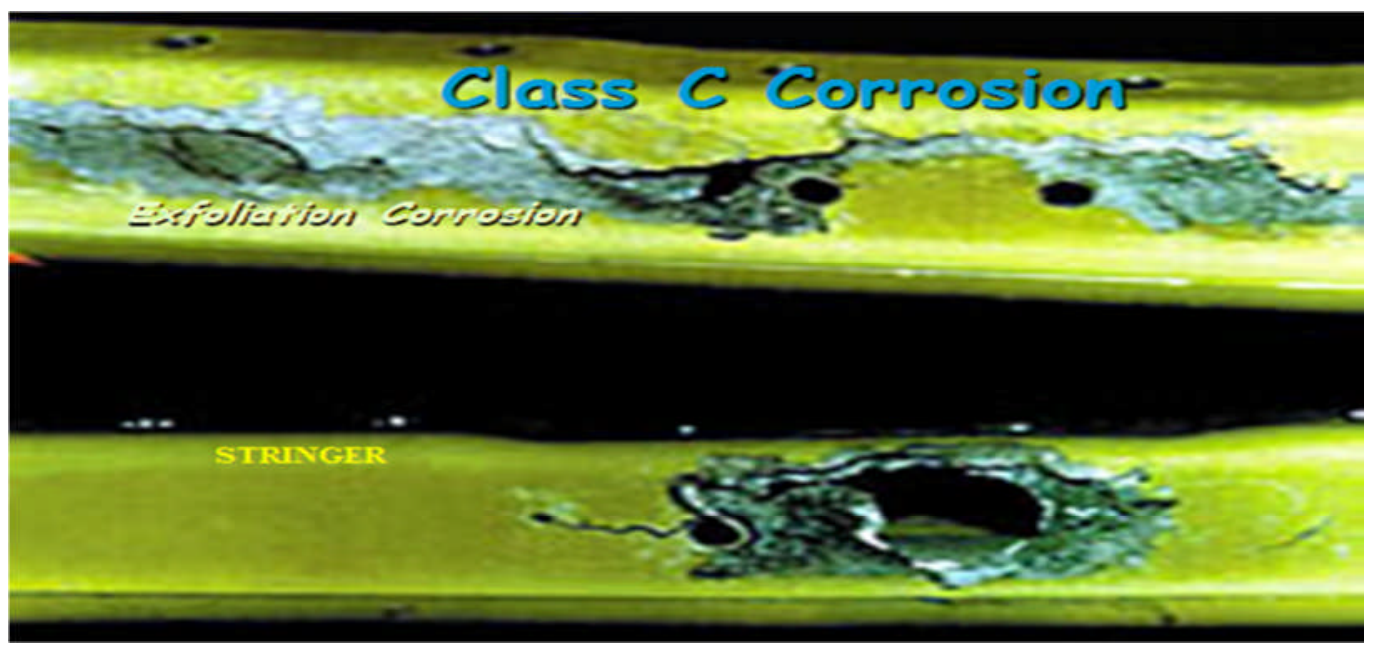

Gambar 3.6. Exfoliation Corrosion 2

\subsection{Galvanic Corrosion}

Korosi tipe ini yang biasa dapat terjadi kapan pun dan dimanapun, dalam kondisi sebagai berikut:

1.Dua buah logam dissimilar terhubung dengan tujuan buat jalur untuk aliran

2. Permukaan material dilapisi dengan beberapa material sebagai elektrolithal ini dapat digantikan saat dimana dissimilar metals skin dirivet,atausaat penggabungan plat aluminium pada struktur dengan steel screw. 


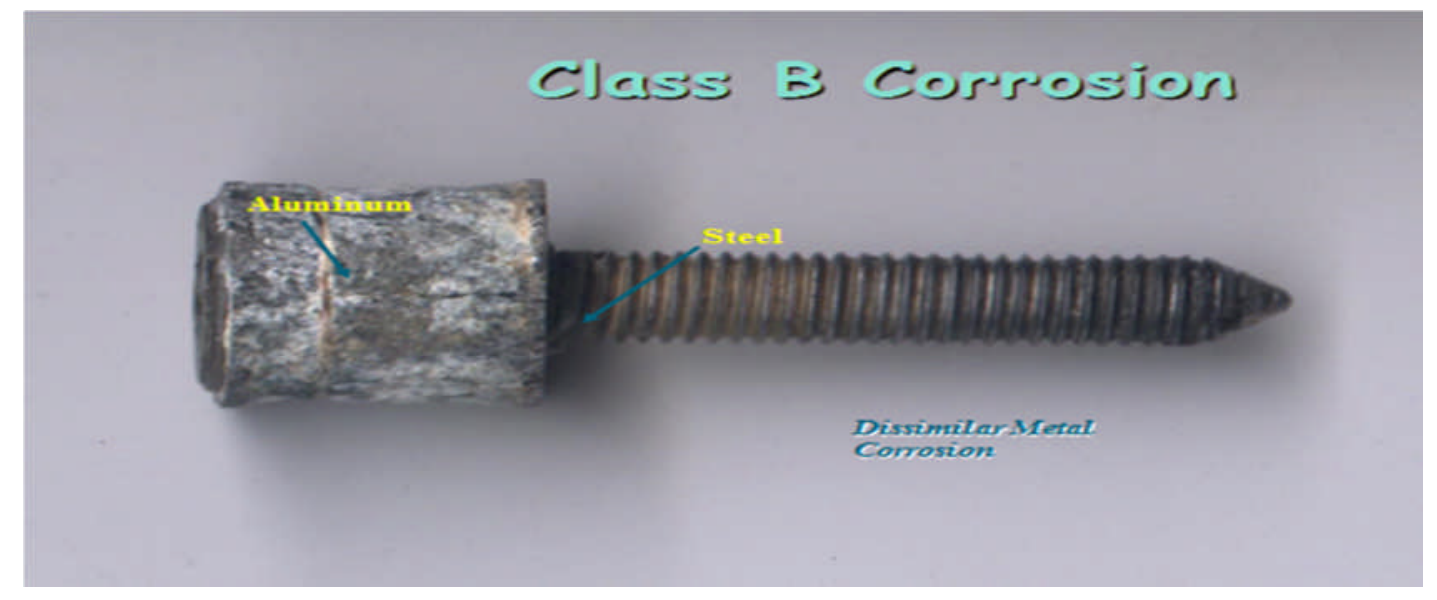

Gambar 3.7.Dissimilar Corrosion

\subsection{Stress Corrosion / Fatique Stess}

Tipe spesial yang lain dari korosi intergranullar adalah stresscorrosion. Ini terjadi saat logam terkena tensile stress. Stress padabisa didapatkan dari ketidaktepatan quenching setelah heattreatment, ataudari interference fit dari fastener. Dari sumber yang lainstress corrosion adalah korosi yang timbul sebagai akibat bekerjanyategangan dan media yang korosifdan ini menyebabkan keretakan.Tegangan adalah tegangan tarik, dapat berupa tegangan sisa ataubekerja. Menurut buku lain stress terjadi sebagai hasil dari efekkombinasi tensile stress dan lingkungan yang korosif( fatique stress). Korosi iniditemukan pada hampir kebanyakan sistem logam, bagaimanapun,karakteristik ini sangat utama bagi aluminium, copper, beberapa,stainless steel, dan high strength-alloy steel (lebih dari 240,00 p.s.i),biasanya terjadi pada cold working dan memungkinkan transgular,intergranular pada alamjenis korosi ini sangat sulit dideteksitanpa menggunakan Ultrasonicatau X-ray.

\section{Ciri-ciri :}

1. Retak menjalar tegak lurus terhadap arah tegangan maksimum

2. Awal retakan dipermukaan dapat berawal dari pitting corrosion 


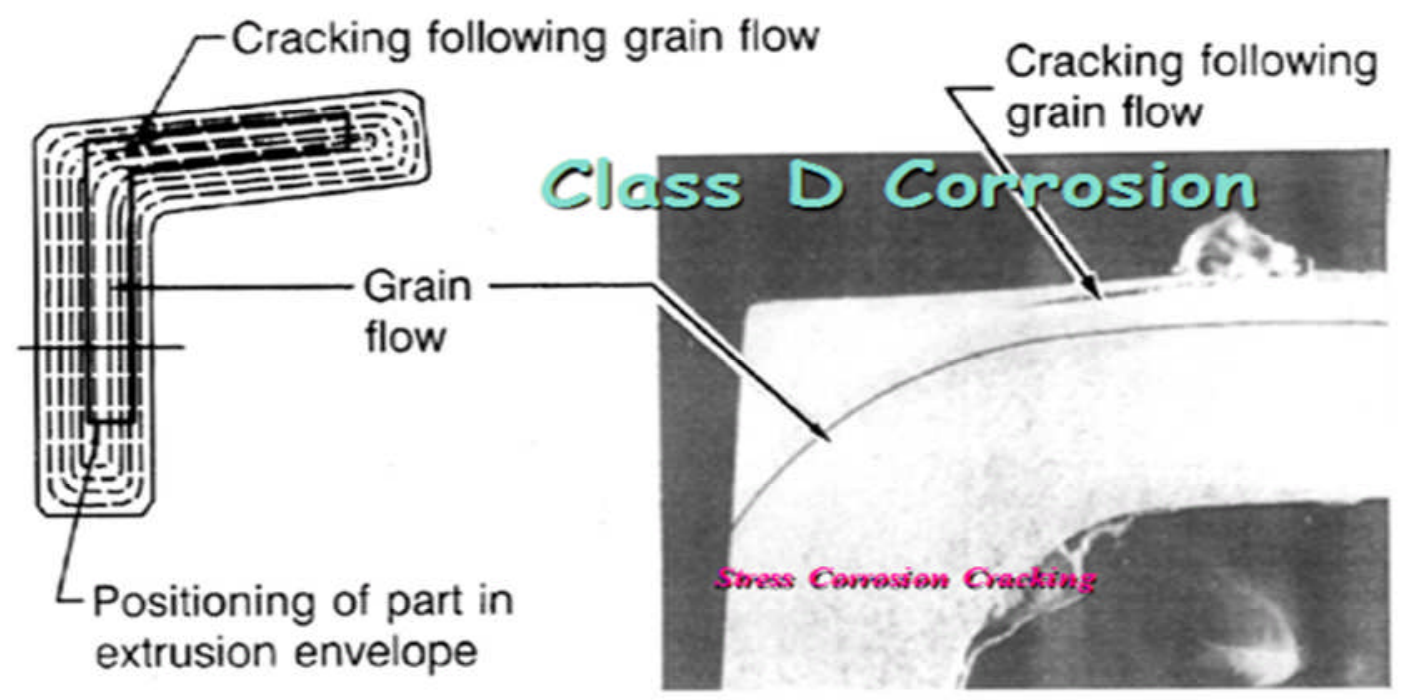

Gambar 3.8. Stress Corrosion Cracking

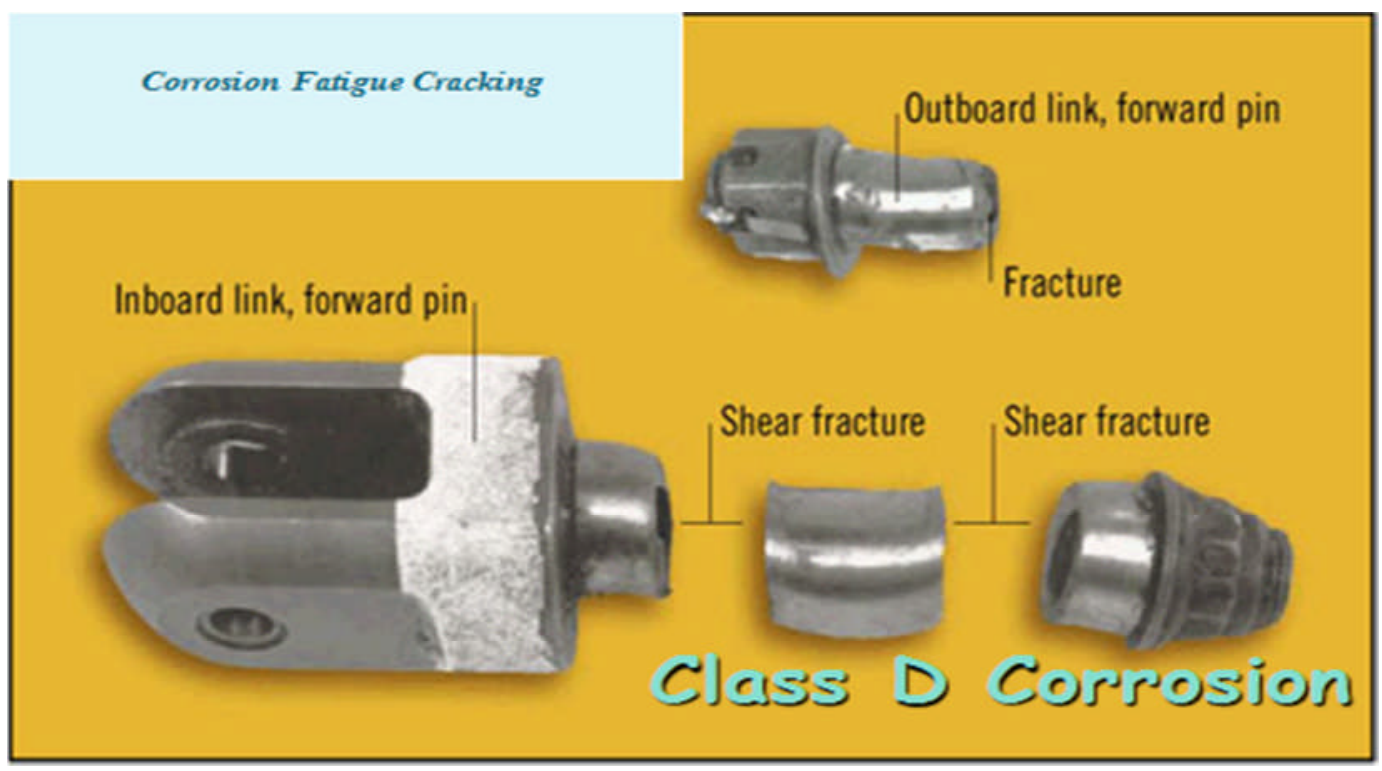

Gambar 3.9. Corrosion Fatique Cracking

\subsection{Microbial Corrosion}

Bentuk korosi yang diakibatkan oleh aktifitas mikro-organisme yang terkandung dalam air ( bakteri, fungus, protoplasma-liquid). Aktifitas mikroorganisme pada garis besarnya adalah merusak lapis pelindung penahan korosi dan menghasilkan endapan / deposit yang kemudian menimbulkan aksi elektrokimia. Sering terjadi pada tangki bahan bakar pesawat yang terkontaminasi oleh air yang mengandung oksida-oksida besi atau garamgaram mineral. 
Penanggulangan :

1. Gunakan lapisan pelindung extra atau lebih tebal.

2. Menambah coating yang spesifik

3. Menambah inhibitor untuk memperburuk kondisi airnya

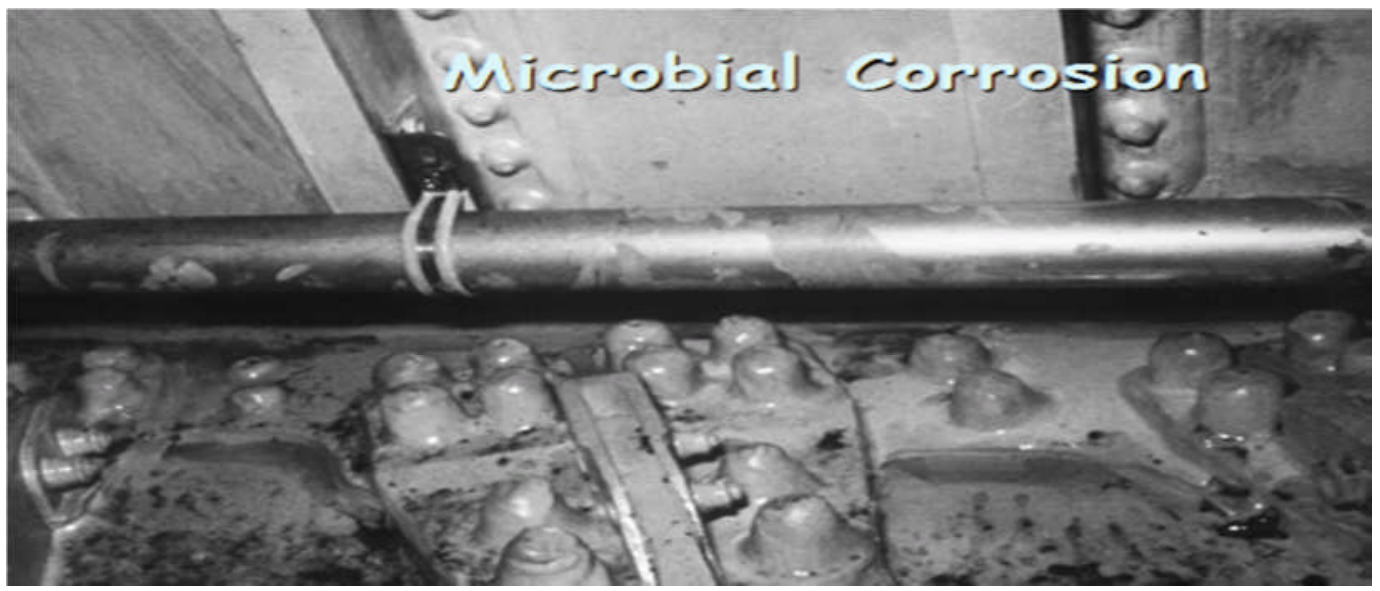

Gambar 3.10. Microbial Corrosion

\subsection{Corrosion Due To Accidental Damage}

Korosi jenis ini sangat bervariasi dapat disebabkan oleh tumpahan air asin /salt water dari marine product, mercury spillage, benturan atau gesekan yang merusak proteksi logam, scratch, dan sebagainya.

\subsection{Corrosion Prevention and Control Program ( CPCP)}

Tujuan dari Corrosion Prevention And Control Program adalah untuk mengontrol terjadinya korosi level satu atau lebih.

Dasar pengerjaan CPCP adalah :

1. Membuka atau mendapatkan jalan ( Gain Access )

2. Inspeksi awal ( Initial Inspections )

3. Bersihkan area ( Clean Area )

4. Inspeksi visual ( Visually Inspections )

5. Olah dan buang semua korosi dan gunakan pelapis pelindung ( Rework

Corrosioan and Reapply Protective Finish)

6. Bersihkan Area pembuangan (Clear Drain Path)

7. Gunakan kompon penghambat korosi ( Apply Corrosion Inhibiting Compound)

8. Gunakan selimut isolasi kering (Dry Insulation Blanket ) 


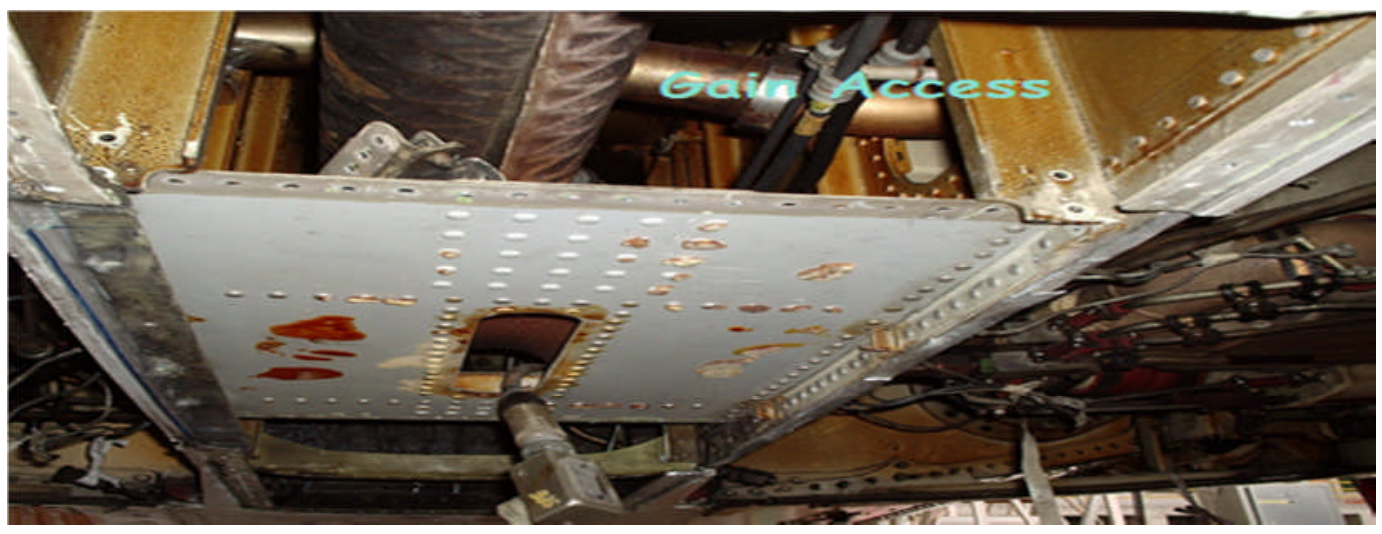

Gambar 3.11.Gain Access

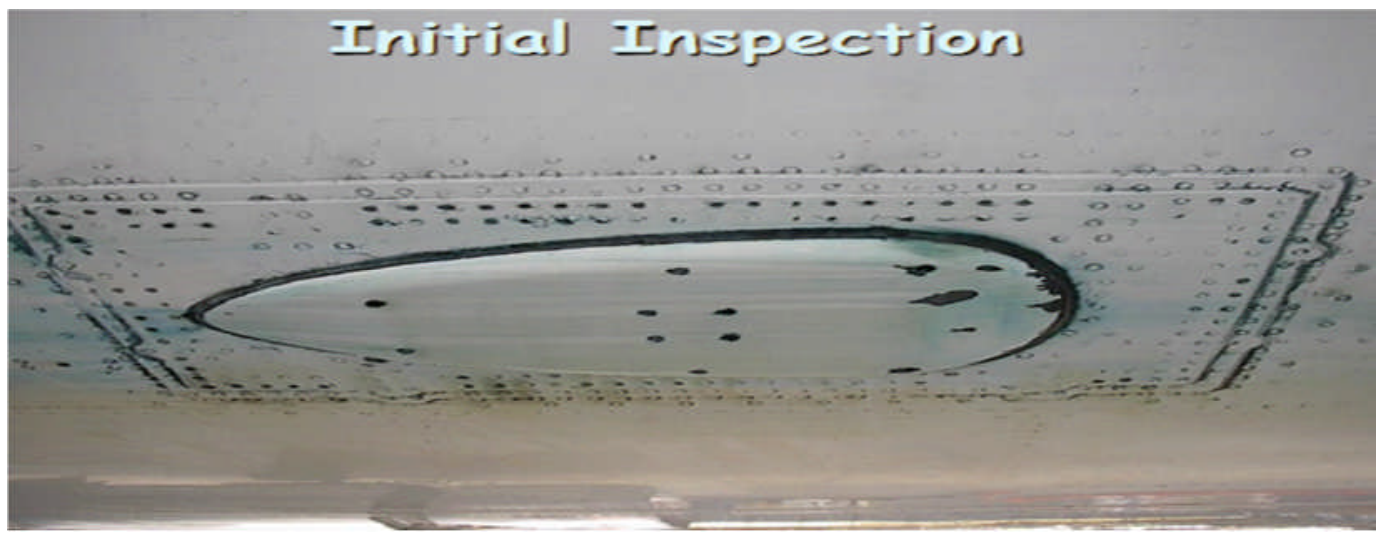

Gambar 3.12. Initial Inspection

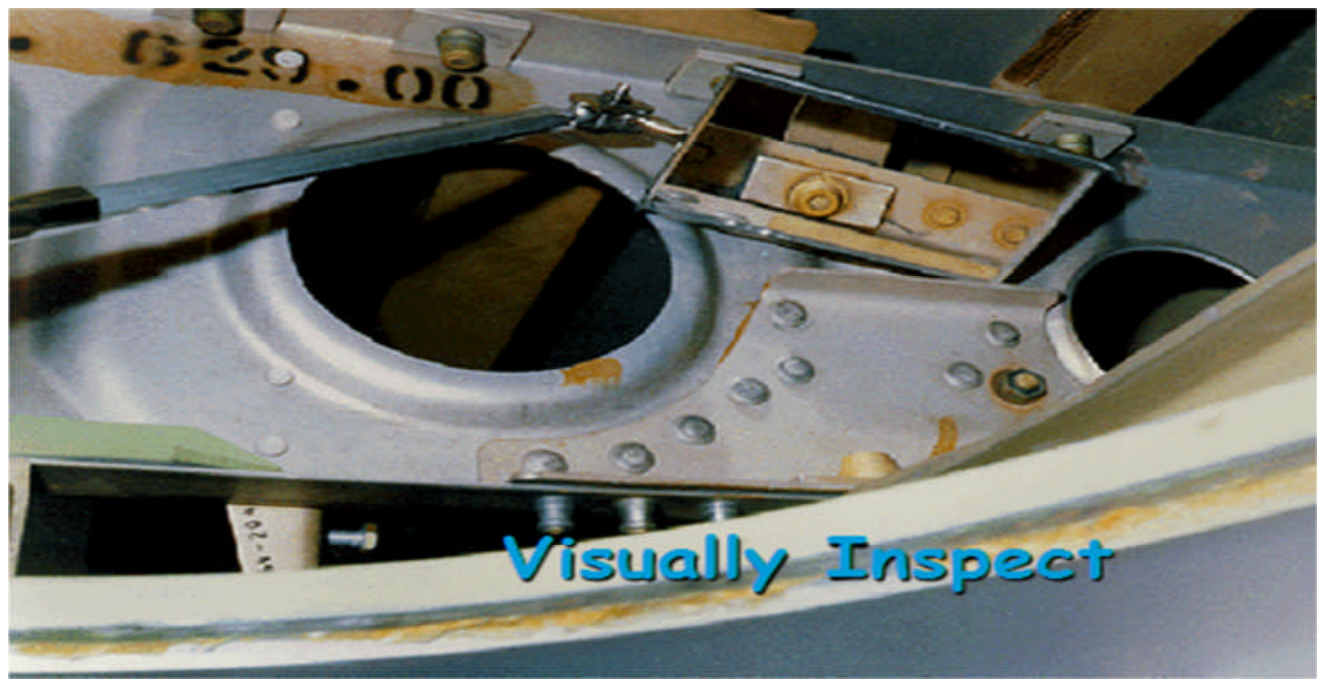

Gambar 3.13. Visually Inspect 


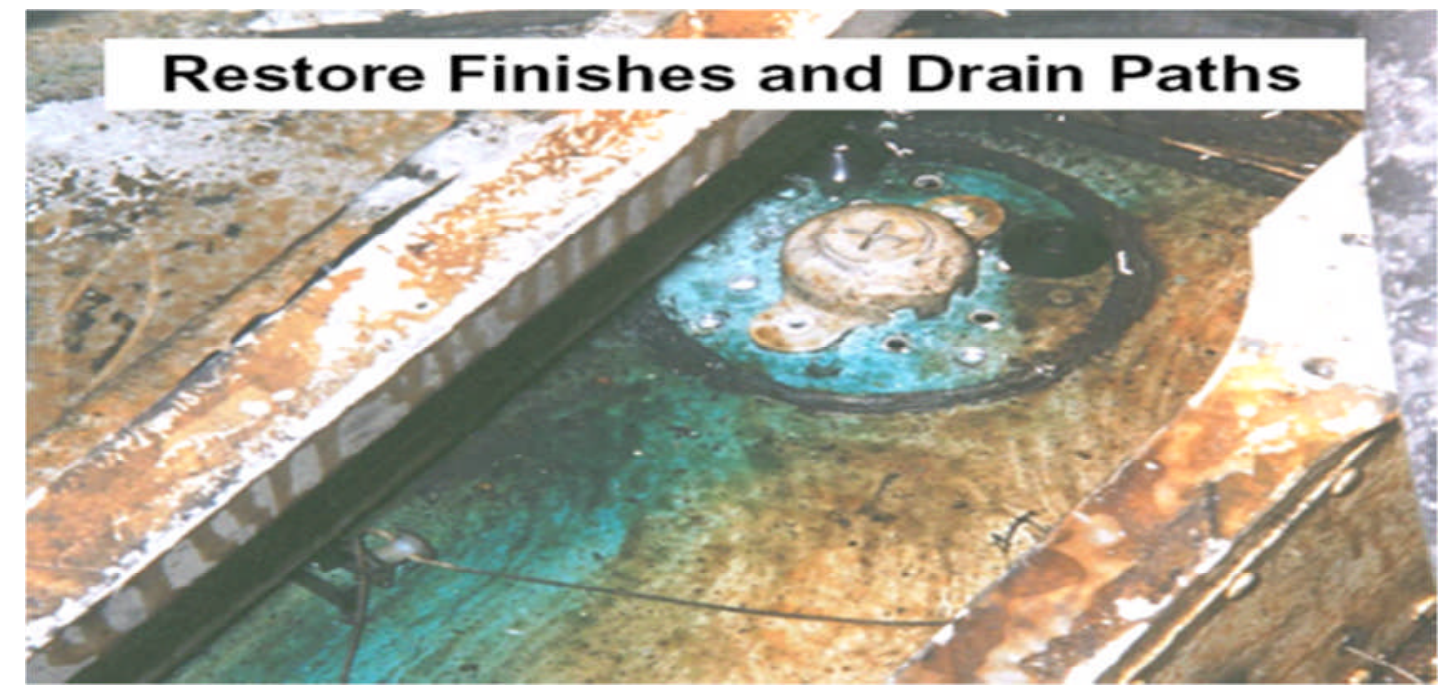

Gambar 3.14. Restore Finishes and Drain Paths

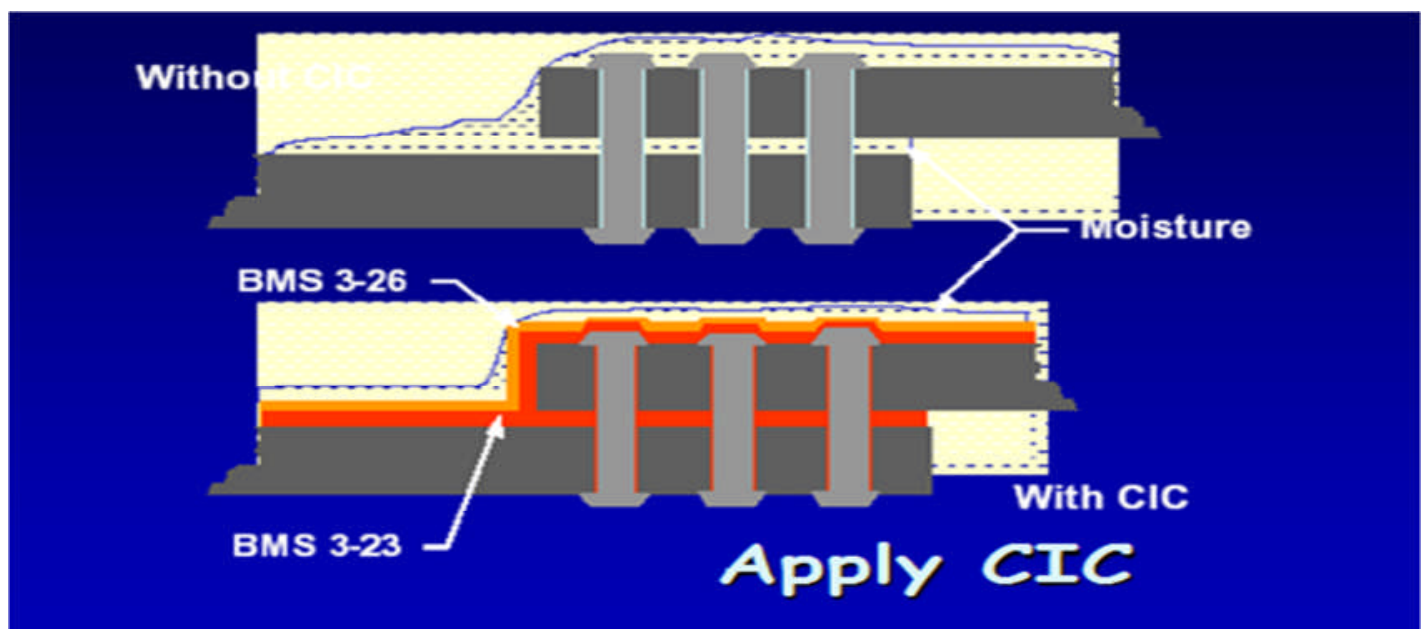

Gambar 3.15. Application of CIC 


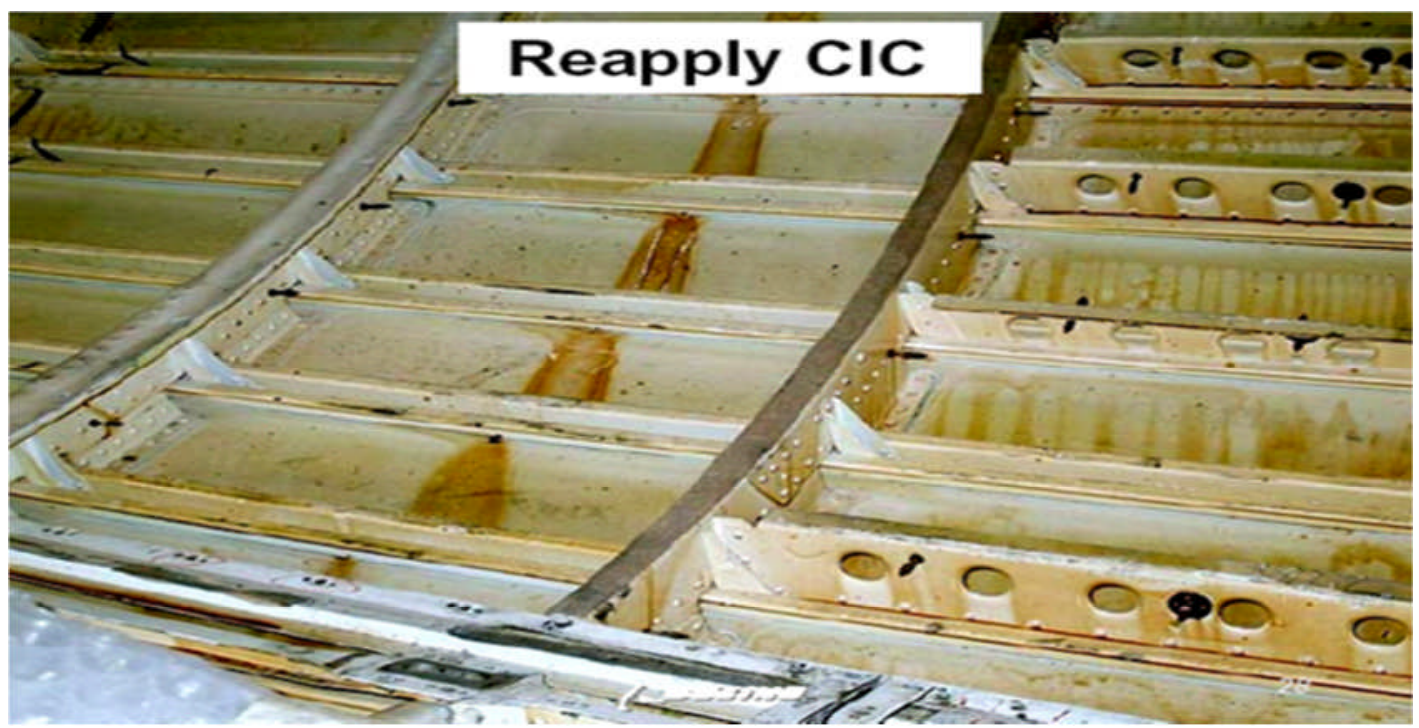

Gambar 3.16. Reapply CIC

Common Types of Corrosion Inhibitors

\begin{tabular}{|c|c|c|c|c|c|c|}
\hline Corrosion Inhibitors & $\begin{array}{l}\text { Common } \\
\text { Dosage } \\
\text { [mg/] }\end{array}$ & $\begin{array}{l}\text { Applicable } \\
\text { PH range }\end{array}$ & Working Principles & Advantages & Limitations & Remarks \\
\hline \multicolumn{7}{|l|}{ Anodic Type } \\
\hline Orthophosphates & $\begin{array}{l}5-20 \\
\left(\text { as } \mathrm{PO}_{4}\right)\end{array}$ & $6.5-8.5$ & $\begin{array}{l}\text { By promoting the } \\
\text { formation of gamma } \\
\text { iron oxide film at the } \\
\text { anode. }\end{array}$ & $\begin{array}{l}\text { - Applicable but no } \\
\text { specific advantage. }\end{array}$ & $\begin{array}{l}\text { - Well control of the system } \\
\text { is required to control } \\
\text { sufficient dissolved } \\
\text { oxygen (DO) in water for } \\
\text { oxide film formation. } \\
\text { - Deposits of iron } \\
\text { phosphate can form } \\
\text { anodes if corrosion starts } \\
\text { and encourages } \\
\text { under-deposit corrosion. } \\
\text { - Formation of } \\
\text { orthophosphate leads to } \\
\text { precipitation of calcium } \\
\text { phosphates. }\end{array}$ & $\begin{array}{l}\text { - Calcium phosphate } \\
\text { scale inhibitors are } \\
\text { always included in } \\
\text { phosphate based } \\
\text { corrosion inhibitor. }\end{array}$ \\
\hline Molybdate & $\begin{array}{l}50-150 \\
\text { (as } \mathrm{MoO}_{4} \text { ) }\end{array}$ & $7.0-8.5$ & $\begin{array}{l}\text { By forming a protective } \\
\text { film of molybdate anions } \\
\text { complex with oxidized } \\
\text { iron. }\end{array}$ & $\begin{array}{l}\text { - Less toxic compare } \\
\text { with chromate. } \\
\text { - Can prevent pitting } \\
\text { corrosion and } \\
\text { underdeposit } \\
\text { corrosion crack. }\end{array}$ & $\begin{array}{l}\text { - Expensive } \\
\text { - Sensitive to chlorine and } \\
\text { sulphate. }\end{array}$ & \\
\hline
\end{tabular}

Tabel 3.1. Type of Corrosion Inhibitors 1 


\begin{tabular}{|c|c|c|c|c|c|c|}
\hline Corrosion Inhibitors & $\begin{array}{l}\text { Common } \\
\text { Dosage } \\
\text { [mgh] }\end{array}$ & $\begin{array}{l}\text { Applicable } \\
\text { PH range }\end{array}$ & Working Principles & Advantages & Limitations & Remarks \\
\hline Nitrite & $250-1000$ & $9-9.5$ & $\begin{array}{l}\text { By promoting the } \\
\text { formation of gamma } \\
\text { iron oxide film at the } \\
\text { anode. }\end{array}$ & $\begin{array}{l}\text { - Applicable but no } \\
\text { specific advantage. }\end{array}$ & $\begin{array}{l}\text { - Subject to biological } \\
\text { degradation, which leads } \\
\text { to the loss of inhibitor and } \\
\text { biofouling problems. } \\
\text { - Require careful control in } \\
\text { open recirculating system } \\
\text { as it can be easily oxidized } \\
\text { to nitrate in open system. }\end{array}$ & \\
\hline \multicolumn{7}{|l|}{ Cathodic Type } \\
\hline $\begin{array}{l}\text { Polyphosphate } \\
\text { (Molecular } \\
\text { dehydrated, } \\
\text { condensed } \\
\text { polymeric, poly and } \\
\text { metaphosphates) }\end{array}$ & $10-20$ & $6.5-8.5$ & $\begin{array}{l}\text { By forming either } \\
\text { calcium or heavy metal } \\
\text { polyphosphate films on } \\
\text { the cathodic surface of } \\
\text { the metal. }\end{array}$ & $\begin{array}{l}\text { - Water quality } \\
\text { insensitive. }\end{array}$ & $\begin{array}{l}\text { - Certain bacterial enzymes } \\
\text { increase the reversion rate } \\
\text { of polyphosphates. } \\
\text { - Formation of } \\
\text { orthophosphate leads to } \\
\text { precipitation of calcium } \\
\text { phosphates. }\end{array}$ & $\begin{array}{l}\text { - Calcium phosphate } \\
\text { scale inhibitors are } \\
\text { always included in } \\
\text { phosphate based } \\
\text { corrosion inhibitor. }\end{array}$ \\
\hline $\begin{array}{l}\text { Organic } \\
\text { Phosphorous } \\
\text { Compounds } \\
\text { (Phosphonates) }\end{array}$ & $10-20$ & $7-9$ & $\begin{array}{l}\text { By forming protective } \\
\text { film on metal surface } \\
\text { with metal ions. }\end{array}$ & $\begin{array}{l}\text { - Water quality } \\
\text { insensitive. } \\
\text { - Phosphonates do not } \\
\text { revert to } \\
\text { orthophosphate, thus } \\
\text { no calcium } \\
\text { orthophosphate } \\
\text { deposition. }\end{array}$ & - No specific limitation. & $\begin{array}{l}\text { - Require either } \\
\text { calcium or metal ion, } \\
\text { such as zinc, for } \\
\text { effective corrosion } \\
\text { inhibition. }\end{array}$ \\
\hline
\end{tabular}

Tabel 3.2. Type of Corrosion Inhibitors 2

\section{PELAKSANAAN PEMERIKSAAN DAN PERBAIKAN}

Persiapan pemeriksaan dengan menggunakan pandangan langsung (Direct Inspection).

1. Pelaksaan pembukaan akses ( Gain access).

2. Penentuan lokasi sesuai kartu kerja.

3. Pembersihan area yang akan di lakukan pemeriksaan atau inspeksi.

4. Pelaksanaan pemeriksaan atau inspeksi.

a. Pemeriksaan visual langsung secara umum.

b. Pemeriksaan secara detail (Detail Visual Inspection ).

c. Menggunakan alat penerang atau senter ( Flash light ).

d. Menggunakan cermin dan kaca pembesar 10 kali ( magnifying glass ).

5, Pencatatan kedalam kartu kerja dan dilaporkan dalam sistem kerja.

6. Pemeriksaan NDT ( Non Destructive Test ), jika diperlukan oleh sebab tidak terjangkaunya atau timbul keraguan akibat keterbatasan mata.

\subsection{Pelaksanaan pekerjaa}

1. Langkah-langkah pekerjaan perbaikan korosi level 1 dituangkan didalam MDR (Maintenance Discrepancy And Rectification ).

a. Buka alat pengencang seperti baut ( bolt), paku keling ( rivet ) Sesuai referensi

b. SRM ( Structure Repai Manual ) Part 51-40-02 Revision Number : 87, March 10/2016

c. Pembersihan area dari korosi dengan referensi SRM part 51-00-07.

d. Pemeriksaan langsung setelah Pembersihan dengan referrensi SRM 
part 51-10-02 paragraf 14.A.5.

e. Jika dalam limitasi langsung gunakan pelindung metal ( Protective

Treatment ) dengan referensi SRM part 51-20-01

d. Pasang kembali alat pengencang seperti baut,rivet sesuai SRM

part 51-40-02

\subsection{Pelaksanaan pekerjaan perbaikan korosi level 2 dan 3.}

Pelaksaan pekerjaan pada level ini langkah-langkahnya sama hanya jika saat pemeriksaan dengan mata langsung atau NDT, ditemukanadanya kerusakan berat, maka di tambahkan langkah-langkahnya yaitu pembuatan bagian yg rusak di workshop atau pembelian dari pabrik langsung.

\section{5.. HASIL DAN PEMBAHASAN}

Perbaikan material yang disebabkan terjadinya korosi pada pesawat udara berasal dari diterbitkanya kartu kerja ( Job Card ) yang diterima dari pelanggan/ operator pesawat yang berisikan perintah-perintah kerja bagian apa saja yang diperiksa bisa juga didalamnya ada item khusus yang dinamakan CPCP ( Corrosion Preventive Control Program ) yang berisi kekhususan perihal korosi. Kemudian jika setelah diperiksa ditemukan ( finding ) mengenai terjadinya korosi maka dituangkan dalam bentuk perintah kerja yang dinamakan MDR ( Maintenance DisdcrepancyAnd Rectification ) yang dibuat oleh seorang pemeriksa ( Inspector ) untuk kemudian diserahkan kepada unit Production Engineering.Diunit ini seorang Engineer membuat langkah-langkah kerja sesuai referensi yang dikeluarkan oleh pabrik yang dinamakan SRM ( Structure Repair Manual ) yang kemudian diserahkan untuk dilakukan oleh produksi ( Mechanic) dilapangan.

Adapun keuntungan yang bisa diraih jika melakukan deteksi awal terjadinya korosi adalah :

1. Memperpanjang usia pakai pada pesawat terbang

2. Cost Efficiency ( efisiensi biaya perawatan )

3. Keamanan dan keselamatan pesawat terbang beserta penumpangnya

4. Jumlah keuntungan atau pendapatan operator pesawat bertambah.

\section{V . PENUTUP}

Korosi merupakan suatu fenomena alam yang tidak bisa dihilangkan namun bisa di cegah kejadianya, dimana terjadi kerusakan logam yang disebabkan reaksi kimia atau elektrokimia sehingga mengubah logam tersebut menjadi campuran logam seperti oxide, hydroxide.

SRM atau structural repair manual adalah pedoman ynag dikeluarkan oleh pabrik pembuat pesawat untuk dijadikan referensi atau acuan dalam setiap melaksanakan perbaikan yang memberi definisi secara detail yang berhubungan 
dengan klasifikasi perbaikan dan pemeriksaan untuk kerusakan yang ditoleransi dan kerusakan tidak ditoleransi serta pendukung yang dapat dipakai. SRM juga berisikan informasi tentang metode perbaikan yang digunakan untuk batasan tertentu pada struktur pesawat terbang.

\section{DAFTAR PUSTAKA}

Chamberlain, ( 1991 )Korosi untuk Mahasiswa dan Rekayasawan.

R.Winston Revie, Herbert H. Uhlig, (2011 ), Corrosion And Corrosion Control,

The Boeing Company, ( 2016 ), General- Fastener Instalation And Removal, SRM 51-40-02, Seattle : Boeing Proprietary.

The Boeing Company,( 2016 ),Corrosion Damage Removal Procedure and Inspection, SRM 51-10-02, Seattle : Boeing Proprietary.

The Boeing Company, ( 2016 ), Allowable Damage, SRM 53-00-07, Seattle : Boeing Proprietary.

The Boeing Company ( 2016 ),General- Protective Treatment Of Metalic AndNonmetalic Repair Part, SRM 51-20-01, Seattle : Boeing Proprietary.

The Boeing Company, ( 2016), Repair Classification And Definition, SRM 51-00-06 Seattle : Boeing Proprietary.

The Boeing Company, ( 2016 ), Aplication Of Interior And Exterior Finishes, Seattle :Boeing Proprietary.

V.S sastri, Edward Ghali, (2007), Mamoun Eboujdaini. Corrosion Prevetion And Protection. 